\title{
RELATIVE EFFICACY OF ORGANIC SUBSTRATES ON MAIZE ROOT PROLIFERATION UNDER WATER STRESS
}

\author{
EFICÁCIA RELATIVA DE SUBSTRATOS ORGÂNICOS NA PROLIFERAÇÃO DE \\ RAÍZES DE MILHO SOB ESTRESSE HIIDRICO
}

\author{
Haroon SHAHZAD ${ }^{1}$; Muhammad IQBAL ${ }^{1}$; Safdar BASHIR ${ }^{1}$; Muhammad FAROOQ ${ }^{2}$ \\ 1. Institute of Soil \& Environmental Sciences, University of Agriculture, Faisalabad, Pakistan. \\ 2. Department of Agronomy, University of Agriculture, Faisalabad, Pakistan. \\ *rhs2140@ymail.com
}

\begin{abstract}
The aggravating threat for today's agriculture is provision of food security to ever-escalating population utilizing scarce resources. Water scarcity is restraining humans to produce more from drops of water in place of gallons. Root is present at soil-plant interface and is main water extractor for plant. Its growth pattern varies as soil moisture conditions fluctuates. Present pot study consisting of two factors i.e. organic substrates (Farm manure, Poultry Manure and Molasses) and different water stress levels \{50, 75, 100 and 125\% of available water contents (AWCs) $\}$ using maize as test crop to assess their impact on different growth parameters (especially root growth). The experiment was conducted using completely randomized design CRD under factorial arrangement. Root length $(44.5 \mathrm{~cm})$, root fresh \& dry biomass $\left(71.1 \mathrm{~g}\right.$ and $24.3 \mathrm{~g}$, respectively), root diameter $(1.73 \mathrm{~mm})$, root volume $\left(0.24 \mathrm{~cm}^{3}\right)$ and root length density $(7.4 \mathrm{x}$ $10^{-3} \mathrm{~cm} \mathrm{~cm}^{-3}$ ) were observed in farm manure treated pots at $75 \%$ AWC that was statistically indistinguishable from all other treatments at same water level and $100 \%$ water availability but eloquently greater than plants of all treatments at $50 \%$ and $125 \%$ available water contents. Shoot length, dry and fresh weights were observed greater in plants having $100 \%$ available moistures. They were statistically at par with $75 \%$ water treated plants. Comparing treatments for all the parameters in multivariate cluster analysis it was concluded that $75 \%$ available water contents produce almost similar to $100 \%$ along with the benefit of water security.
\end{abstract}

KEYWORDS: Organic. Maize. Root. Proliferation. Drought.

\section{INTRODUCTION}

Plant roots are major contributors of organic matter and structural stability of soil, directly through root material itself, and indirectly through stimulation of rhizosphere biological activities. They are involved in particle aggregation, more importantly polysaccharide molecules secretion. Glomalin production by mycorrhizae (RILLIG et al., 2002) play central role in aggregation that had been explicitly evidenced (SCHREINER et al., 1997). Counter production of exopolysaccharides (EPS) by rhizosphere microbiota modifies soil structure of sunflower root surfaces vicinity, counteracting the negative impact of water deficit on plant growth (ALAMI et al., 2000).

Water and its movement through soil-plantatmosphere is crucial for photosynthesis, enzyme activity, metabolite transpiration and productivity of growing grains (NACEU et al., 1999). Evapotranspiration, is a main component of water balance (GENTINE et al., 2007; PARASURAMAN et al., 2007) and grain yields can be described as a linear function of total evapotranspiration (ET) for most crops (VAUX; PRUITT, 1983). Scheduled irrigation at different growth stages can improve water use efficiency according to several studies
(WANG et al., 2002; FANG et al., 2010). JIN et al. (1999) also found that over irrigation can decrease crop water use efficiency, while deficit irrigation may result in more production and WUE. Kang et al. (2002) also reported that grain yield and water use efficiency were strongly affected by soil water contents and irrigation schedules.

Arid climate, extensive cultivation, residue burning, exhaustive crop rotation and mismanagement had lead the soils to possess organic carbon less than $1 \%$, that was the reason for conduction of numerous studies with organic substrates. Chief drive was to determine their nutrient equivalence with synthetic fertilizers and their non-nutrient benefits (TANDON, 1997). Long term experiments showed "fatigue" symptoms, witnessing stagnant and declined yields (DAWE et al., 2000; DUXBURY et al., 2000; LADHA et al., 2003). The major reason put forward for this stagnant yield was decline in organic matter quality and quantity (DAWE et al., 2000; YADAV et al., 2000; LADHA et al., 2003). Long term fertilizer management, manure and compost application, residue incorporation, green manuring, reduced or zero tillage, crop rotation and waste land restoration enhanced soil carbon buildup and storage (KIMBLE et al., 2002). These practices not only sustained the 
soil carbon but also productivity of crops. Single management strategy won't be effective for carbon sequestration and yield enhancement (LAL, 2004).

Based upon above facts it was hypothesized that artificial organic materials decompose to boost nutritional capacity of soil. Therefore, this experiment was envisaged to assess the impact of organic substrates addition in soil on maize vegetative growth under water stress.

\section{MATERIAL AND METHODS}

A pot experiment was carried out at wire house Institute of Soil \& Environmental Sciences, University of Agriculture, Faisalabad, Pakistan. Experimental site, which has typical tropical monsoon climate with $30{ }^{\circ} \mathrm{C}$ and $705 \mathrm{~mm}$ mean annual temperature and precipitation, respectively. Mean annual accumulated temperature above $10{ }^{\circ} \mathrm{C}$ is $33.5^{\circ} \mathrm{C}$. Approximately, $80 \%$ annual precipitation comes during March to September. Soil for the experiment was collected from field area of Institute of Soil \& Environmental Sciences (Latitude
SHAHZAD, H. et al.

$31^{\circ} 26^{\prime} 0^{\prime \prime} \mathrm{N}$ and longitude $\left.73^{\circ} 08^{\prime} 0^{\prime \prime} \mathrm{E}\right)$, University of Agriculture, Faisalabad, Pakistan. Soil was sandy clay loam, semi-active, isohyperthermic Typic Calciargids (FAO Classification). Each pot had 45 $\mathrm{cm}$ height and $20 \mathrm{~cm}$ diameter and was filled with $10 \mathrm{~kg}$ soil. The bulk density of soil was maintained as $1.36 \mathrm{Mg} \mathrm{m}^{-3}$ during pot filling. Soil samples were collected from depth of $0-15 \mathrm{~cm}$, crop roots and other debris were removed from samples and soil was air dried prior to pass through $2 \mathrm{~mm}$ sieve. Soil samples contained $9 \mathrm{~g} \mathrm{~kg}^{-1}$ soil organic carbon (SOC), $1.2 \mathrm{~g} \mathrm{~kg}^{-1} \mathrm{~N}, 7.5$ (C: N), 8.2 units of pH. Soil water retention capacity was measured by predefined matric potential (DANE; HOPMANS, 2002) with the help of suction plates at 0.3, 0.6, 1.0, 3.0 and 4.5 bar pressure and a linear regression equation was calculated by taking $\ln (\mathrm{h})$ versus $\ln \theta /$ $\theta_{\mathrm{s}}$ to find water contents at field capacity $\left(\theta_{\mathrm{FC}}\right)$ and permanent wilting point $\left(\theta_{\mathrm{PWP}}\right)$ of soil (WILLIAMS et al., 1983). Following equation was developed by taking $\ln (\mathrm{h})$ versus $\ln \theta / \theta_{\mathrm{s}}$ to get $\left(\theta_{\mathrm{FC}}\right)$ and $\left(\theta_{\mathrm{PWP}}\right)$ etc.

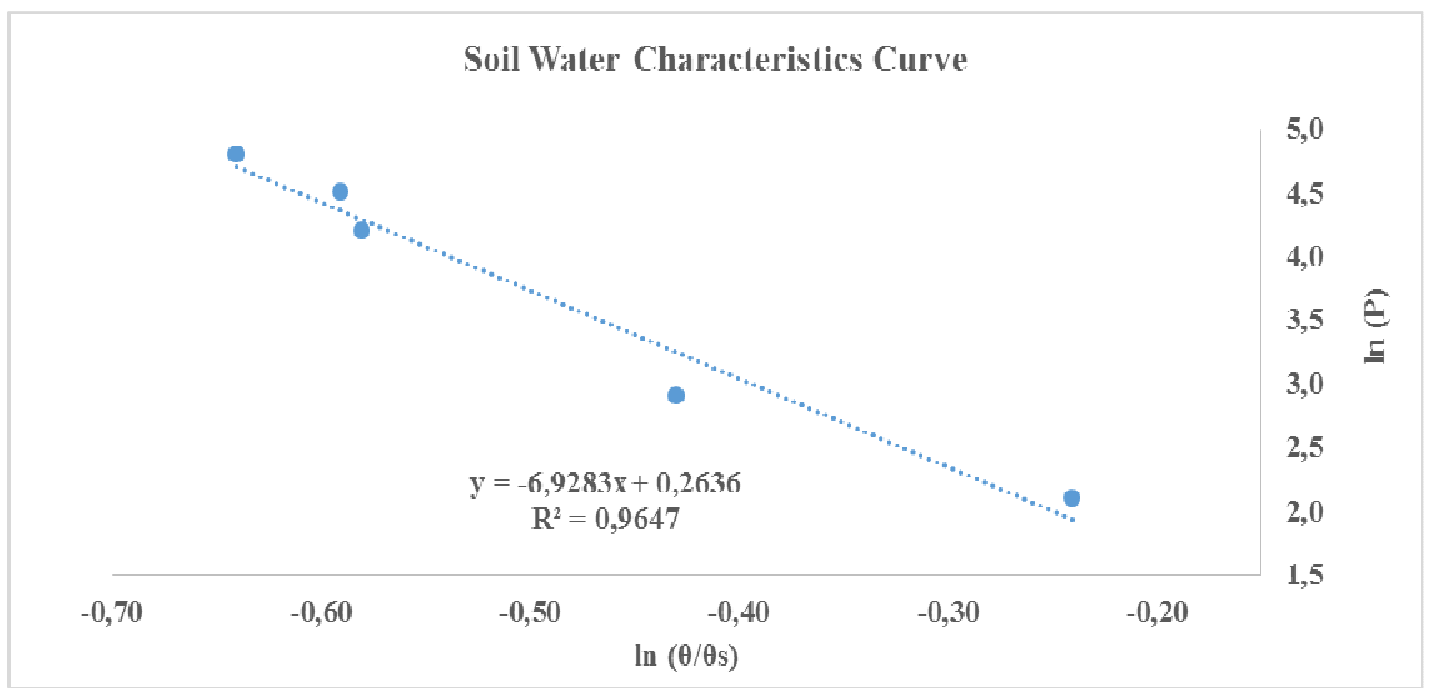

Figure1. Water characteristics curve

$\ln P=\ln \mathrm{P}_{\alpha}+\mathrm{b} \ln \left(\theta / \theta_{\mathrm{s}}\right)$

$P$ is matric potential (k Pa), " $\mathrm{P}$ " (intercept) is air entry value/ bubbling pressure that has inverse relation with " $\alpha$ ", and "b" is slope of $\ln P v s \theta / \theta_{\mathrm{s}}$ of water retention curve. The linear relationship between $\ln \theta / \theta_{\mathrm{s}}$ [-] and $\ln (\mathrm{P})[\mathrm{kPa}]$ were observed for experimental soil with intercept $(0.26)$ and a negative slope -6.9283 (Figure 1). Water retention properties of experimental soil are presented in Table 1

The experiment was laid out in CRD under factorial arrangement with water stress levels as one factor and organic amendments (Farm Manure,
Poultry Manure and Molasses) as other factor with three replications. Four water stress levels $(50,75$, 100 and $125 \%$ of AWC) were designed to subject maize crop to water stress and the other treatments (organic substrates) were mixed with soil at the time of filling of pots as being described in treatment plan.

Each treatment was replicated thrice. During the whole study, controlled irrigation was applied to each pot by weighing pot on daily basis using weighing balance, so as to accurately maintain water stress level followed by said experimental design. Locally manufactured digital balance was used for 
weighing that had weighing capacity in range from $200-30000 \pm 5 \mathrm{~g}$.

Table1. Water Retention properties of soil used for pot filling
Water Retention Properties
$\Theta_{\mathrm{S}}$
$\Theta_{\mathrm{FC}}$
$\Theta_{\text {PWP }}$
$\boldsymbol{\Theta}_{\text {AWC }}$

\begin{tabular}{|c|c|c|}
\hline \multirow{2}{*}{ Units } & \multicolumn{2}{|c|}{$(\%)$} \\
\hline & $45.4 \pm 1.32$ & $10.9 \pm 0.67$ \\
\hline \multicolumn{3}{|c|}{ Data is average of three replicates with standard error } \\
\hline \multicolumn{3}{|c|}{ Treatment Plan } \\
\hline $50 \%$ AWC & & $100 \%$ AWC \\
\hline $\mathrm{CTRL}_{50}=$ Control & & $\mathrm{CTRL}_{100}=$ Control \\
\hline $\mathrm{FM}_{50}=$ Farm Manure & & $\mathrm{FM}_{100}=$ Farm Manure \\
\hline $\mathrm{PM}_{50}=$ Poultry Manure & & $\mathrm{PM}_{100}=$ Poultry Manure \\
\hline $\mathrm{MO}_{50}=$ Molasses & & $\mathrm{MO}_{100}=$ Molasses \\
\hline $75 \%$ AWC & & $125 \%$ AWC \\
\hline $\mathrm{CTRL}_{75}=$ Control & & $\mathrm{CTRL}_{125}=$ Control \\
\hline $\mathrm{FM}_{75}=$ Farm Manure & & $\mathrm{FM}_{125}=$ Farm Manure \\
\hline $\mathrm{PM}_{75}=$ Poultry Manure & & $\mathrm{PM}_{125}=$ Poultry Manure \\
\hline $\mathrm{MO}_{75}=$ Molasses & & $\mathrm{MO}_{125}=$ Molasses \\
\hline
\end{tabular}

Data was collected according to Dwyer et al. (1987) and irrigation amount was calculated to replace depleted water content from each pot according to designed treatments. Hybrid maize Shahnshah was planted on $9^{\text {th }}$ of March 2014. Urea was applied @ $120 \mathrm{~kg} \mathrm{ha}^{-1}$ in two splits (at the time of $1^{\text {st }}$ and $2^{\text {nd }}$ irrigation) while phosphorus and potash were applied @ $60 \mathrm{~kg} \mathrm{ha}^{-1}$ at the time of sowing. Seedling density after germination was controlled to one plant per pot and weeds were removed by hand. At $25^{\text {th }}$ of April soil from the pots was evacuated using water to take out the roots at the time of harvest. Plant height was measured with meter rod and fresh weight of root and shoot was measured using weight balance. Shoot was subjected to drying at $70{ }^{\circ} \mathrm{C}$ in oven till constant weight and then calculated using weighing balance. Plant roots were separated using dissection needle in water filled glass container and the sketch of these extended roots is being taken using root scanner (hp-scanjet 2700). These scanned roots then inserted to root scanning software (RootSnap) to find average root length, root volume and root diameter (Dannoura et al., 2008). Then again these roots were oven dried at $70{ }^{\circ} \mathrm{C}$ to take their dry mass. Root length density $\left(\mathrm{cm} \mathrm{cm}^{-3}\right)$ was calculated by equation

Root Length Density $=\frac{\text { Average Root Length }}{\text { Volume of the Pot }}$
All treatments were tested for significance at $(p>0.05)$ using analysis of variance technique. Significance of individual treatments was tested using Tuckey's Honestly Significant Difference (HSD) test (Montgomery, 2013). Better performing treatments were categorized using multivariate (Cluster analysis) technique.

\section{RESULTS}

\section{Plant Height}

Table 2 explicates the variation in plant height of maize with amalgamated application of organic substrates, while soil moisture was kept 50, 75,100 and $125 \%$ of soil available water capacity. Table evidenced increase in length of plants with increasing moisture content up to $100 \%$ AWC that lessened upon further increase.

Tallest plants $(90.0 \mathrm{~cm})$ were found in treatment where farm manure was applied $\left(\mathrm{FM}_{50}\right)$ at $50 \%$ moisture level. Plants of $\mathrm{FM}_{50}$ were statistically similar but 7.18, 0.9 and $5 \%$ longer in length than $\mathrm{CTRL}_{50}, \mathrm{PM}_{50}$ and $\mathrm{MO}_{50}$ treatments, respectively. Increased soil moisture resulted in more elongated plants as $157.6 \mathrm{~cm}$ in $\left(\mathrm{PM}_{75}\right)$ that was at par with $\mathrm{FM}_{75}$ and $\mathrm{MO}_{75}$ which have only 2.56 and $5.77 \%$ dwarfed plants, respectively. All 
treated soils yielded significantly longer plants than control soil at $75 \%$ moisture level. Plant height was observed maximum $(158.5 \mathrm{~cm})$ in $\mathrm{FM}_{100}$ that was at par with $\mathrm{PM}_{100}$ and $\mathrm{MO}_{100}$ but was significantly greater than control. At $125 \%$ moisture plant height declined to $62.7 \mathrm{~cm}$ in $\mathrm{MO}_{125}$ that was at par with all other treated plots at same moisture.

Plant height increased from $84.0 \mathrm{~cm}$ at $50 \%$ AWC to 135.5 and $138.7 \mathrm{~cm}$ at 75 and $100 \%$ AWC then decreased to $60.3 \mathrm{~cm}$ at oversaturation. Farm manure application had maximum plant height $158.5 \mathrm{~cm}$ at $100 \%$ available capacity that was 3 , 76.1 and $158.7 \%$ greater in conditions possessing moisture @ 75, 50 and 125\% of available water capacities, respectively. Poultry litter application in soil had given rise 157.6, 155.8, 89.2 and $56.1 \mathrm{~cm}$ long plants while the moisture was kept @ 75, 100, 50 and $125 \%$ available moistures. Molasses application also had longest $154.9 \mathrm{~cm}$ plants where moisture was at $100 \%$ of AWC that got declined to $149,85.7$ and $62.7 \mathrm{~cm}$ in 75,50 and $125 \%$ AWCs.

\section{Shoot Fresh Weight}

Table 2 overt disparity in fresh weights of plants with application of organic substrates at different $(50,75,100,125 \%)$ available moistures. It is evidenced from Table that increase in moisture yields more plant weights from 50\% to $100 \%$ AWC that depreciated upon saturation.

Table 2. Effect of organic substrates application at different moisture levels on plant height, fresh and dry weights of maize shoot

\begin{tabular}{|c|c|c|c|c|c|}
\hline AWC & $\begin{array}{c}\text { Organic } \\
\text { Amendments }\end{array}$ & Treatments & $\begin{array}{c}\text { Plant Height } \\
(\mathrm{cm})\end{array}$ & $\begin{array}{c}\text { Shoot Fresh } \\
\text { Weight (g) }\end{array}$ & $\begin{array}{l}\text { Shoot Dry Weight } \\
\text { (g) }\end{array}$ \\
\hline \multirow{4}{*}{$50 \%$} & CTRL & $\mathrm{CTRL}_{50}$ & $84 \pm 2.27 \mathrm{~d}$ & $65 \pm 1.89 \mathrm{e}$ & $25.6 \pm 0.76 \mathrm{e}$ \\
\hline & $\mathrm{FM}$ & $\mathrm{FM}_{50}$ & $90.0 \pm 2.76 \mathrm{~d}$ & $72.9 \pm 1.48 \mathrm{de}$ & $28.8 \pm 0.59 \mathrm{de}$ \\
\hline & PM & $\mathrm{PM}_{50}$ & $89.2 \pm 2.21 \mathrm{~d}$ & $70.5 \pm 2.37 \mathrm{de}$ & $27.8 \pm 0.97 \mathrm{de}$ \\
\hline & MO & $\mathrm{MO}_{50}$ & $85.7 \pm 3.57 \mathrm{~d}$ & $72 \pm 6.18 \mathrm{de}$ & $28.3 \pm 2.41 \mathrm{de}$ \\
\hline \multirow{4}{*}{$75 \%$} & CTRL & $\mathrm{CTRL}_{75}$ & $135.5 \pm 1.99 \mathrm{c}$ & $74.5 \pm 2.35 \mathrm{c}-\mathrm{e}$ & $29.3 \pm 0.97 \mathrm{~cd}$ \\
\hline & FM & $\mathrm{FM}_{75}$ & $153.7 \pm 1.97 \mathrm{a}-\mathrm{c}$ & $99.3 \pm 3.40 \mathrm{a}-\mathrm{c}$ & $39 \pm 1.36 \mathrm{ab}$ \\
\hline & $\mathrm{PM}$ & $\mathrm{PM}_{75}$ & $157.6 \pm 3.27 \mathrm{ab}$ & $99.6 \pm 3.25 \mathrm{a}-\mathrm{c}$ & $39.1 \pm 1.31 \mathrm{ab}$ \\
\hline & MO & $\mathrm{MO}_{75}$ & $149 \pm 4.30 \mathrm{a}-\mathrm{c}$ & $88.4 \pm 4.02$ a-e & $34.8 \pm 1.61 \mathrm{~d}$ \\
\hline \multirow{4}{*}{$100 \%$} & CTRL & CTRL $_{100}$ & $138.7 \pm 2.50 \mathrm{bc}$ & $77.2 \pm 4.00 \mathrm{~b}-\mathrm{e}$ & $30.3 \pm 1.52 \mathrm{de}$ \\
\hline & FM & $\mathrm{FM}_{100}$ & $158.5 \pm 3.42 \mathrm{a}$ & $106.1 \pm 4.76 \mathrm{a}$ & $41.7 \pm 1.88 \mathrm{a}$ \\
\hline & PM & $\mathrm{PM}_{100}$ & $155.8 \pm 5.63 \mathrm{ab}$ & $91.4 \pm 0.99 \mathrm{a}-\mathrm{d}$ & $35.9 \pm 0.39 \mathrm{~d}$ \\
\hline & MO & $\mathrm{MO}_{100}$ & $154.9 \pm 2.84 \mathrm{ab}$ & $99.5 \pm 3.32 \mathrm{a}-\mathrm{c}$ & $39 \pm 1.28 \mathrm{ab}$ \\
\hline \multirow{4}{*}{$125 \%$} & CTRL & CTRL $_{125}$ & $60.3 \pm 2.63 \mathrm{e}$ & $64.2 \pm 3.72 \mathrm{e}$ & $25.1 \pm 1.44 \mathrm{e}$ \\
\hline & FM & $\mathrm{FM}_{125}$ & $61.3 \pm 0.93 \mathrm{e}$ & $75 \pm 8.31 \mathrm{c}-\mathrm{e}$ & $29.4 \pm 3.25 \mathrm{de}$ \\
\hline & $\mathrm{PM}$ & $\mathrm{PM}_{125}$ & $56.1 \pm 2.89 \mathrm{e}$ & $72.6 \pm 7.41 \mathrm{de}$ & $28.5 \pm 2.97 \mathrm{de}$ \\
\hline & MO & $\mathrm{MO}_{125}$ & $62.7 \pm 2.60 \mathrm{e}$ & $68.5 \pm 2.20 \mathrm{de}$ & $26.9 \pm 0.80 \mathrm{de}$ \\
\hline
\end{tabular}

Abbreviations: AWC (Available water contents), CTRL (Control), FM (Farm Manure), PM (Poultry Manure) and MO (Molasses)

At $100 \%$ available moisture $106.1 \mathrm{~g}$ fresh shoot weight of maize plant was found in pots treated with farm manure, which was statistically at par with other waste treated pots but was significantly greater than control. Poultry manure had yielded $106.1 \mathrm{~g}$ fresh weight of plants at $75 \%$ available moisture that was $0.3,12.8$ and $33.8 \%$ greater in weight than $\mathrm{FM}_{75}, \mathrm{MO}_{75}$ and $\mathrm{CTRL}_{75}$, respectively. $72.9 \mathrm{~g}$ fresh weight of plants was there of farm manure treated soils at $50 \%$ available 
moisture capacity that was 1.2, 3.4 and $12.3 \%$ greater in content than $\mathrm{MO}_{50}, \mathrm{PM}_{50}$ and $\mathrm{CTRL}_{50}$, respectively. Oversaturation affected the plant biomass in all the treatments, as $75 \mathrm{~g}$ biomass was found in pots treated with farm manure that was 3.3, 9.4 and $16.8 \%$ greater than $\mathrm{PM}_{125}, \mathrm{MO}_{125}$ and $\mathrm{CTRL}_{125}$, respectively.

Moisture had an impact on plant growth as $100 \%$ water availability yielded $77.2 \mathrm{~g}$ biomass that was 3.6, 18.8 and $20.25 \%$ greater than pots in which soil water content were maintained @ 75, 50 and $125 \%$ of AWCs. Combination of farm manure and $100 \%$ available water had maximum biomass $(106.1 \mathrm{~g})$ production that was statistically like the mass $(99.3 \mathrm{~g})$ produced at $75 \%$ moisture but was suggestively greater than 75 and $72.9 \mathrm{~g}$ where water was maintained @ 125 and 50\% of AWC. $99.6 \mathrm{~g}$ biomass was produced by unified application of poultry and $75 \%$ water availability that is suggestively identical to $100 \%$ AWC but significantly higher than $72.6 \mathrm{~g}$ and $70.5 \mathrm{~g}$, where waterwas maintained @ 125 and 50\% of AWCs.

\section{Shoot Dry Weight}

Table 2 unconcealed discrepancy in shoot dry weights using organic substrates in combination with different $(50,75,100,125 \%)$ available moistures. It can be demonstrated from Table that moisture increase produces more dry matter up to $100 \%$ AWC but oversaturation declines the dry matter addition.

Optimum available moisture (100\% AWC) produced $41.7 \mathrm{~g}$ dry plant biomass in pots treated with farm manure $\left(\mathrm{FM}_{100}\right)$, that had not a suggestive alteration from molasses treated (39.0) but pointedly greater than $35.9 \mathrm{~g}$ and $30.3 \mathrm{~g}$ biomass produced by poultry and untreated plants. Poultry manure @ 75\% AWC had generated 39.1 g dry biomass which was $0.17,12.6$ and $33.7 \%$ greater in weight than $\mathrm{FM}_{75}, \mathrm{MO}_{75}$ and CTRL 75 , respectively. Farm manure yielded $28.8 \mathrm{~g}$ dry heft at 50\% AWC that was 1.5, 3.64 and $12.6 \%$ greater in content than $\mathrm{MO}_{50}, \mathrm{PM}_{50}$ and $\mathrm{CTRL}_{50}$, respectively. Dry matter addition was declined in each treatment with oversaturation generating only $29.43 \mathrm{~g}$ in farm manure treated pots that was 2.21 , 9.4 and $17.1 \%$ greater than $\mathrm{PM}_{125}, \mathrm{MO}_{125}$ and CTRL $_{125}$, respectively.

Maximum dry matter $39.1 \mathrm{~g}$ was produced by farm manure and $100 \%$ water retention combination engendering $8.9,41.0$ and $37.0 \%$ greater biomass than plants grown @ 75, 50 and $125 \%$ of AWCs. Control produced (30.3 g) dry shoot matter at $100 \%$ AWC that was statistically at par with $75 \%$ moisture but was provocatively, greater than dry weights produced @ 125 and 50\% of AWC. $39.1 \mathrm{~g}$ biomass was produced by application of poultry @ 75\% water availability that is defiantly indistinguishable from $100 \%$ AWC but wittingly higher than $28.5 \mathrm{~g}$ and $27.7 \mathrm{~g}$, where water was maintained @ 125 and 50\% of AWCs.

\section{Root Length}

Variation in length of plant root with application of organic amendments under different moisture levels has been particularized in Table 3. Roots of $11.29 \mathrm{~cm}$ length were measured for the plants treated with molasses where moisture was maintained at 50\% AWC that was 13.5, 17.1 and $21.9 \%$ longer than $\mathrm{PM}_{50}, \mathrm{FM}_{50}$ and CTRL $\mathrm{C}_{50}$. 44.6, 41.7 and $40.1 \mathrm{~cm}$ long roots in $\mathrm{FM}_{75}, \mathrm{PM}_{75}$ and $\mathrm{MO}_{75}$ treatments evidenced 4.62, 4.2 and 3.55 times elongation than $50 \%$ available moisture. Slight and non-suggestive diminution in length of roots $\left(43.1\left(\mathrm{FM}_{100}\right), 40.4\left(\mathrm{PM}_{100}\right)\right.$ and $40.0\left(\mathrm{MO}_{100}\right)$ $\mathrm{cm})$ was found with increase in available water contents to $100 \%$, and are challengingly stretched by $39.5,30.9$ and $29.7 \%$ than control. Strong decrement $(7.81,6.93,7.84$ and $7.23 \mathrm{~cm})$ in root proliferation was observed upon saturation in nontreated and treated soils.

\section{Root Fresh and Dry Weight}

Effect of different organic substrates at different moisture levels on weight of plant roots is elucidated in Table 3. It is evident from this table that combination of farm manure at $75 \%$ available water yielded highest root fresh and dry weights (71.1 and $24.3 \mathrm{~g}$ ) that were only (0.88 and $4.24 \mathrm{~g}$ ) and $(0$ and $1.19 \mathrm{~g})$ greater than weights of roots in molasses and poultry treated plants. All of the treated roots have significantly greater fresh and dry biomasses than control. Plant roots in $\mathrm{PM}_{100}$, $\mathrm{FM}_{100}$ and $\mathrm{MO}_{100}$ have fresh and dry weights of order $(63.5,63$ and $60.6 \mathrm{~g})$ and $(21.9,21.7$ and 21 g) that were statistically similar but were significantly greater than control (42 and $14.5 \mathrm{~g}$ ). (20.4 and $7.02 \mathrm{~g}$ ) and (14.3 and $4.97 \mathrm{~g}$ ) fresh and dry weights of roots were found at 50 and $125 \%$ AWCs that were at par with all of the treatments. 
Table 3. Effect of organic substrates application at different moisture levels on length, fresh and dry weights of maize root

\begin{tabular}{cccccc}
\hline AWC & $\begin{array}{c}\text { Organic } \\
\text { Amendments }\end{array}$ & Treatments & $\begin{array}{c}\text { Root Length } \\
(\mathbf{c m})\end{array}$ & $\begin{array}{c}\text { Root Fresh Weight } \\
(\mathbf{g})\end{array}$ & $\begin{array}{c}\text { Root Dry } \\
\text { Weight }(\mathbf{g})\end{array}$ \\
\hline \multirow{2}{*}{$\mathbf{5 0 \%}$} & $\mathrm{CTRL}$ & $\mathrm{CTRL}_{50}$ & $9.26 \pm 1.43 \mathrm{c}$ & $20.4 \pm 1.83 \mathrm{~g}-\mathrm{i}$ & $7.02 \pm 1.10 \mathrm{c}$ \\
& $\mathrm{FM}$ & $\mathrm{FM}_{50}$ & $9.64 \pm 1.23 \mathrm{c}$ & $22.3 \pm 1.19 \mathrm{gh}$ & $7.67 \pm 1.10 \mathrm{c}$ \\
& $\mathrm{PM}$ & $\mathrm{PM}_{50}$ & $9.95 \pm 0.97 \mathrm{c}$ & $23.6 \pm 1.11 \mathrm{~g}$ & $7.78 \pm 0.86 \mathrm{c}$ \\
$\mathbf{7 5 \%}$ & $\mathrm{MO}$ & $\mathrm{MO}_{50}$ & $11.3 \pm 0.55 \mathrm{c}$ & $24.3 \pm 1.42 \mathrm{~g}$ & $7.13 \pm 1.17 \mathrm{c}$ \\
& $\mathrm{CTRL}$ & $\mathrm{CTRL}_{75}$ & $34.7 \pm 0.87 \mathrm{~b}$ & $47.2 \pm 1.04 \mathrm{f}$ & $16.3 \pm 1.17 \mathrm{~b}$ \\
& $\mathrm{FM}$ & $\mathrm{FM}_{75}$ & $44.6 \pm 1.11 \mathrm{a}$ & $71.1 \pm 1.27 \mathrm{a}$ & $24.3 \pm 2.39 \mathrm{a}$ \\
& $\mathrm{PM}$ & $\mathrm{PM}_{75}$ & $41.7 \pm 0.70 \mathrm{a}$ & $67 \pm 1.84 \mathrm{a}-\mathrm{d}$ & $23.1 \pm 2.73 \mathrm{a}$ \\
& $\mathrm{MO}$ & $\mathrm{MO}_{75}$ & $40.1 \pm 0.46 \mathrm{a}$ & $70.3 \pm 1.30 \mathrm{ab}$ & $24.3 \pm 3.09 \mathrm{a}$ \\
& $\mathrm{CTRL}$ & $\mathrm{CTRL}_{100}$ & $30.9 \pm 1.05 \mathrm{~b}$ & $42 \pm 1.01 \mathrm{f}$ & $14.5 \pm 1.45 \mathrm{~b}$ \\
& $\mathrm{FM}$ & $\mathrm{FM}_{100}$ & $43.1 \pm 0.79 \mathrm{a}$ & $63 \pm 1.72 \mathrm{c}-\mathrm{e}$ & $21.7 \pm 2.99 \mathrm{a}$ \\
& $\mathrm{PM}$ & $\mathrm{PM}_{100}$ & $40.4 \pm 0.68 \mathrm{a}$ & $63.5 \pm 0.80 \mathrm{~b}-\mathrm{e}$ & $21.9 \pm 2.62 \mathrm{a}$ \\
& $\mathrm{MO} \%$ & $\mathrm{MO}_{100}$ & $40 \pm 1.02 \mathrm{a}$ & $60.6 \pm 1.41 \mathrm{de}$ & $20.9 \pm 2.81 \mathrm{a}$ \\
& $\mathrm{MO}$ & $\mathrm{CTRL}_{125}$ & $7.81 \pm 0.55 \mathrm{c}$ & $14.3 \pm 1.65 \mathrm{ij}$ & $5.00 \pm 0.88 \mathrm{c}$ \\
& $\mathrm{FTR}$ & $\mathrm{FM}_{125}$ & $6.93 \pm 0.30 \mathrm{c}$ & $15.2 \pm 1.18 \mathrm{ij}$ & $5.08 \pm 0.22 \mathrm{c}$ \\
& $\mathrm{FM}$ & $\mathrm{PM}_{125}$ & $7.84 \pm 0.31 \mathrm{c}$ & $15.1 \pm 0.95 \mathrm{ij}$ & $5.18 \pm 0.65 \mathrm{c}$ \\
& $\mathrm{MO}$ & $7.23 \pm 0.38 \mathrm{c}$ & $12.2 \pm 1.12 \mathrm{j}$ & $4.10 \pm 0.47 \mathrm{c}$ \\
\hline
\end{tabular}

Abbreviations: AWC (Available Water Contents), CTRL (Control), FM (Farm Manure), PM (Poultry Manure) and MO (Molasses)

\section{Root Length Density}

Root length density is one of the authoritative parameter that determines plant anchorage, crop stand, water and nutrient uptake from soil. Disparity in length density of plant roots in organic substrate pot cultures at several moisture levels is presented in Figure 2. It is illustrated that 75 and $100 \%$ moisture yielded denser long roots than other two moisture levels. Farm manure yielded maximum $7.40 \times 10^{-3} \mathrm{~cm} \mathrm{~cm}^{-3}$ root length density at $75 \%$ moisture that was at par with $100 \%$ moisture $\left(7.13 \times 10^{-3}\right) \mathrm{cm} \mathrm{cm}^{-3}$ but was 4.6 and 6.54 folds denser than 50 and $125 \%$ moistures, respectively. $6.9 \times 10^{-3} \mathrm{~cm} \mathrm{~cm}^{-3}$ root length density was found in poultry blended cultures at $75 \%$ moisture that was statistically analogous to $100 \%$ moisture but was 4.23 and 5.3 times denser than roots in 50 and $125 \%$ available moistures. Molasses mixture yielded $6.3 \times 10^{-3} \mathrm{~cm} \mathrm{~cm}^{-3}$ length density of roots at $100 \%$ moisture availability that was statistically undistinguishable to $75 \%$ moisture level. Their combination yielded only $1.87 \times 10^{-3}$ and $1.2 \times 10^{-3} \mathrm{~cm} \mathrm{~cm}^{-3}$ denser roots at 50 and $125 \%$ moistures that were 3.57 and 5.56 times lesser than root length density in $75 \%$ moisture level.

Farm manure had $7.4 \times 10^{-3} \mathrm{~cm} \mathrm{~cm}^{-3}$ root length density @ 75\% moisture that was 7.2, 11.61 and $28.2 \%$ greater than $\mathrm{PM}_{75}, \mathrm{MO}_{75}$ and $\mathrm{CTRL}_{75}$. At $100 \%$ available water, maximum root length density $\left(7.13 \times 10^{-3} \mathrm{~cm} \mathrm{~cm}^{-3}\right)$ was found in $\mathrm{FM}_{100}$ that was statistically at par with $\mathrm{PM}_{100}\left(6.73 \times 10^{-3}\right)$ and $\mathrm{MO}_{100}\left(6.67 \times 10^{-3}\right)$ but was 1.35 times extra than CTRL $_{100}\left(5.13 \times 10^{-3}\right) \mathrm{cm} \mathrm{cm}^{-3} .1 .97 \times 10^{-3} \mathrm{~cm} \mathrm{~cm}^{-3}$ dense roots were found in $\mathrm{MO}_{50}$ at $50 \%$ AWC that was 20.9, 23.1 and 28.8\% lager in content than $\mathrm{PM}_{50}, \mathrm{FM}_{50}$ and CTRL 50 , respectively. Plants treated with poultry manure had $1.3 \times 10^{-3} \mathrm{~cm} \mathrm{~cm}^{-3}$ dense roots @ 125\% AWC that was 3.17, 8.33 and 15\% denser than CTRL $L_{125}, \mathrm{MO}_{125}$ and $\mathrm{FM}_{125}$, respectively. 


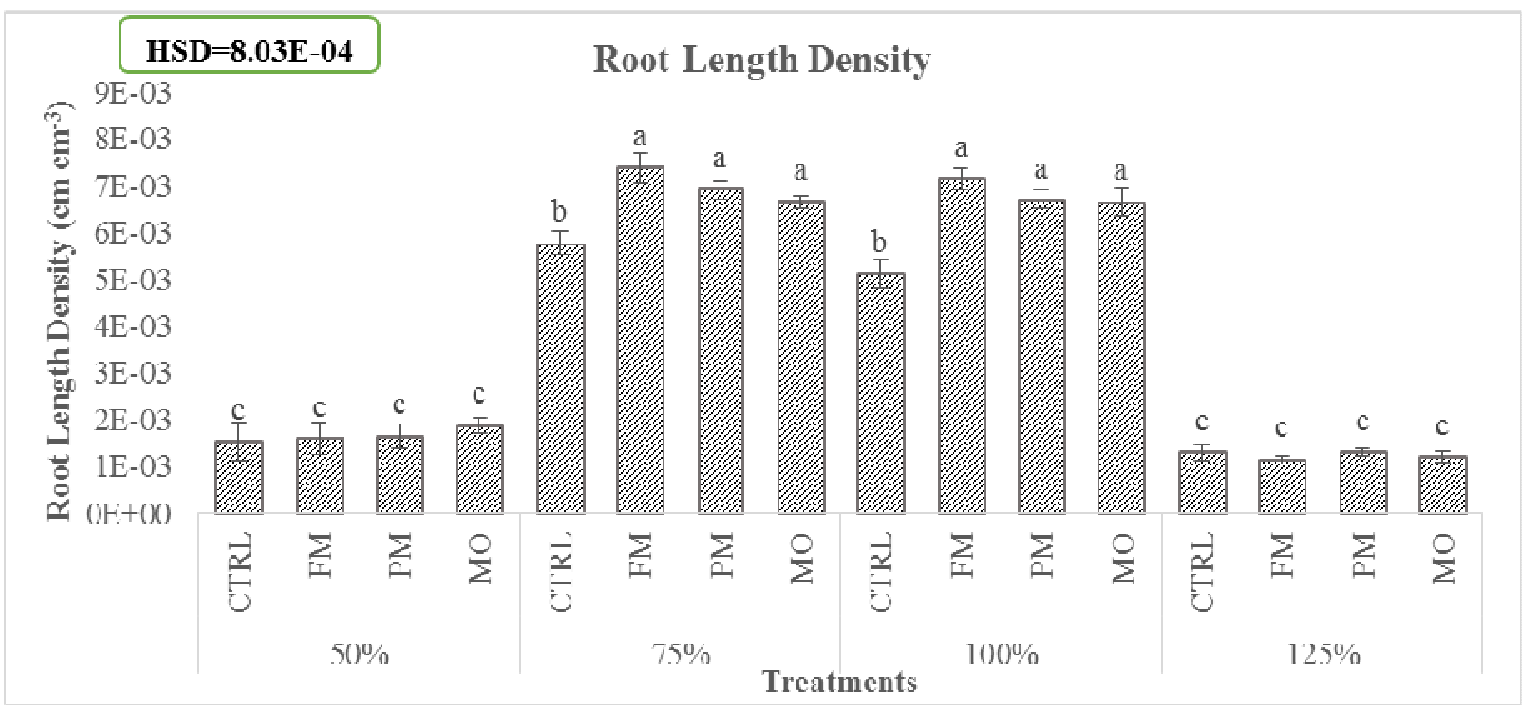

Figure 2. Effect of different organic substrates on root length density $\left(\mathrm{cm} \mathrm{cm}^{-3}\right)$ at different water stress levels

\section{Root Volume}

Figure 3 enlightens the vicissitudes in volume of roots upon application of organic substrates at different soil moistures. Roots of untreated control at $75 \%$ AWC occupied $0.15 \mathrm{~cm}^{3}$ space that was alluringly lower than $0.22,0.21$ and $0.206 \mathrm{~cm}^{3}$ in $\mathrm{FM}_{75}, \mathrm{PM}_{75}$ and $\mathrm{MO}_{75}$, respectively. Volume of roots in molasses treated pots $\left(0.21 \mathrm{~cm}^{3}\right)$ was appealingly akin farm manure $\left(0.20 \mathrm{~cm}^{3}\right)$ and poultry $\left(0.19 \mathrm{~cm}^{3}\right)$ blends but meaningfully greater than control $\left(0.145 \mathrm{~cm}^{3}\right)$ at $100 \%$ available moisture. $0.12 \mathrm{~cm}^{3}$ volume was covered by roots of untreated plants at $50 \%$ moisture that was enticingly similar with $\mathrm{FM}_{50}, \mathrm{PM}_{50}$ and $\mathrm{MO}_{50}$, respectively. Molasses blend of soil @ $125 \%$ moisture had occupied $0.11 \mathrm{~cm}^{3}$ volume in soil that is statistically similar with $0.11,0.10$ and $0.10 \mathrm{~cm}^{3}$ in farm manure, poultry and control, respectively.
Soil kept at $50 \%$ supported plant to extend its roots to occupy volume of $0.12 \mathrm{~cm}^{3}$ that was $20 \%$ greater than pots in which moisture was maintained @ 125\% AWC but volume was 25 and $20.8 \%$ lesser than pots in which water was maintained at 75and $100 \%$ of available water capacities. Plant roots of farm manure blended soil had covered $0.22 \mathrm{~cm}^{3}$ volume@75\% available water that was at par with $100 \%$ moisture but was pointedly greater than plants in 50 and $125 \%$ water retaining soils. $0.21 \mathrm{~cm}^{3}$ volume was occupied by plants at $75 \%$ moisture in poultry amended soils that was analogous to 0.194 $\mathrm{cm}^{3}$ at $100 \%$ moisture but was pointedly more than root volume at 50 and $125 \%$ available moistures. Plants grown in soil treated with molasses @ 100\% AWC have root volume of $0.21 \mathrm{~cm}^{3}$ that was equal to volume at $75 \%$ AWC but possessed 50 and $91 \%$ more volume than soils at 50 and $125 \%$ available moistures.

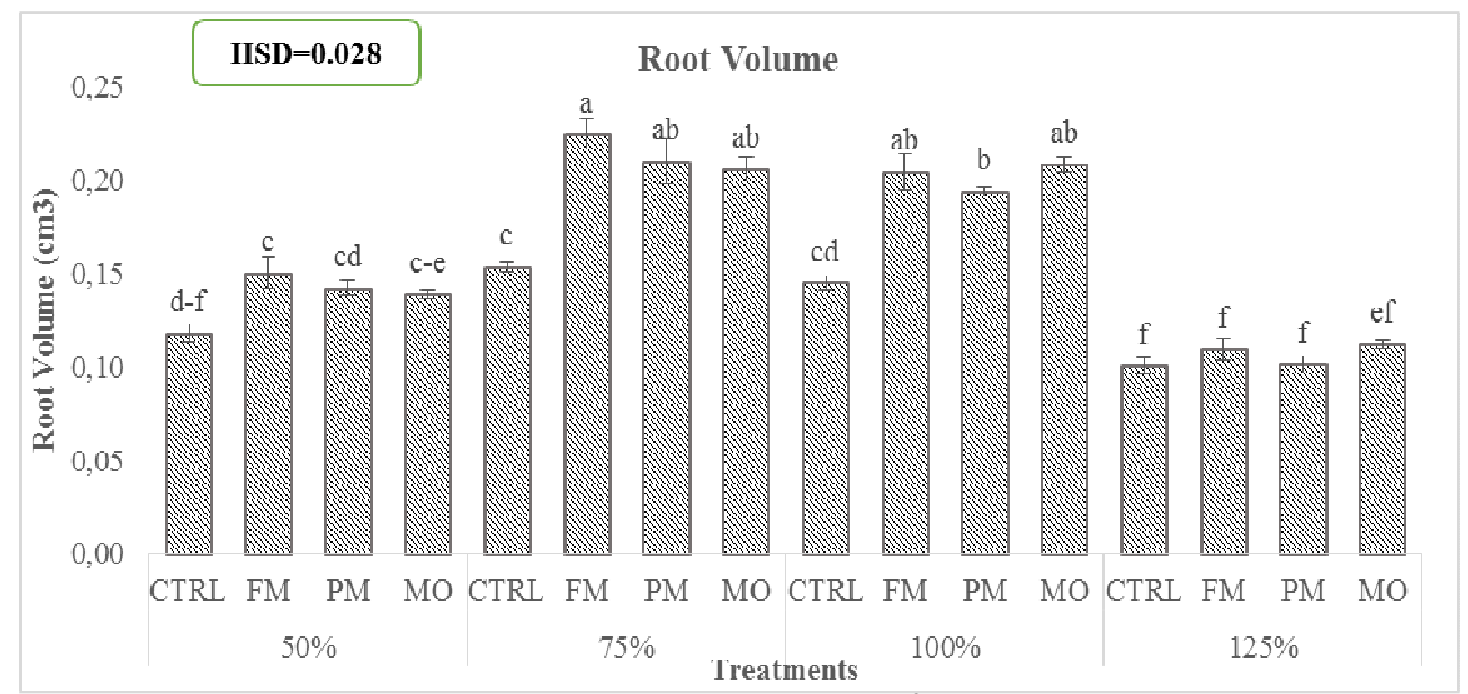

Figure 3. Effect of different organic substrates on root volume $\left(\mathrm{cm}^{3}\right)$ at different water stress levels 


\section{Root Average Diameter}

Figure 4 elucidates the changes in average diameter of root with application of organic substrates while soil water content was maintained at different levels. Data regarding water content reveals roots of $100 \%$ water retained soil having 1.1 $\mathrm{mm}$ diameter was statistically similar to $75 \%$ but was 1.86 and 2.11 times messier than $125 \%$ and $50 \%$ moisture levels. Blend of farm manure with soil had roots with average diameters of $1.73 \mathrm{~mm}$ at $75 \%$ moisture that was only $2.7 \%$ messier than roots in $100 \%$ moisture but had 2.92 and 3.14 times more diameter than 125 and $50 \%$ available moistures, respectively. Combination of poultry manure with soil had managed to formulate roots of $1.65 \mathrm{~mm}$ diameter at $75 \%$ available water that possessed 0.02 , 1.05 and $1.14 \mathrm{~mm}$ more diameter than 100, 50 and
$125 \%$ moisture. Plant roots of molasses treated soils had $1.68 \mathrm{~mm}$ average diameter at $75 \%$ available soil moisture that was statistically alike to that of $100 \%$ moisture level but had 2.95 and 3.3 times more diameter than pots having 50 and $125 \%$ moistures. $75 \%$ moisture in combination with farm manure give rise the thicker roots of average diameter 1.73 $\mathrm{mm}$ that were statistically at par with $\mathrm{PM}_{75}$ and $\mathrm{MO}_{75}$ but was significantly more thick than CTRL $_{100}$. At $100 \%$ moisture roots of $\mathrm{FM}_{100}$ had 1.68 $\mathrm{mm}$ diameter which was only $0.3,0.3$ and $0.5 \mathrm{~mm}$ more than $\mathrm{MO}_{100}$ and $\mathrm{PM}_{100}$, respectively, but was suggestively thicker than CRRL $_{100}(1.1 \mathrm{~mm})$. Roots of plants in treated as well as control at 50 and $125 \%$ moisture were observed to be statistically similar.

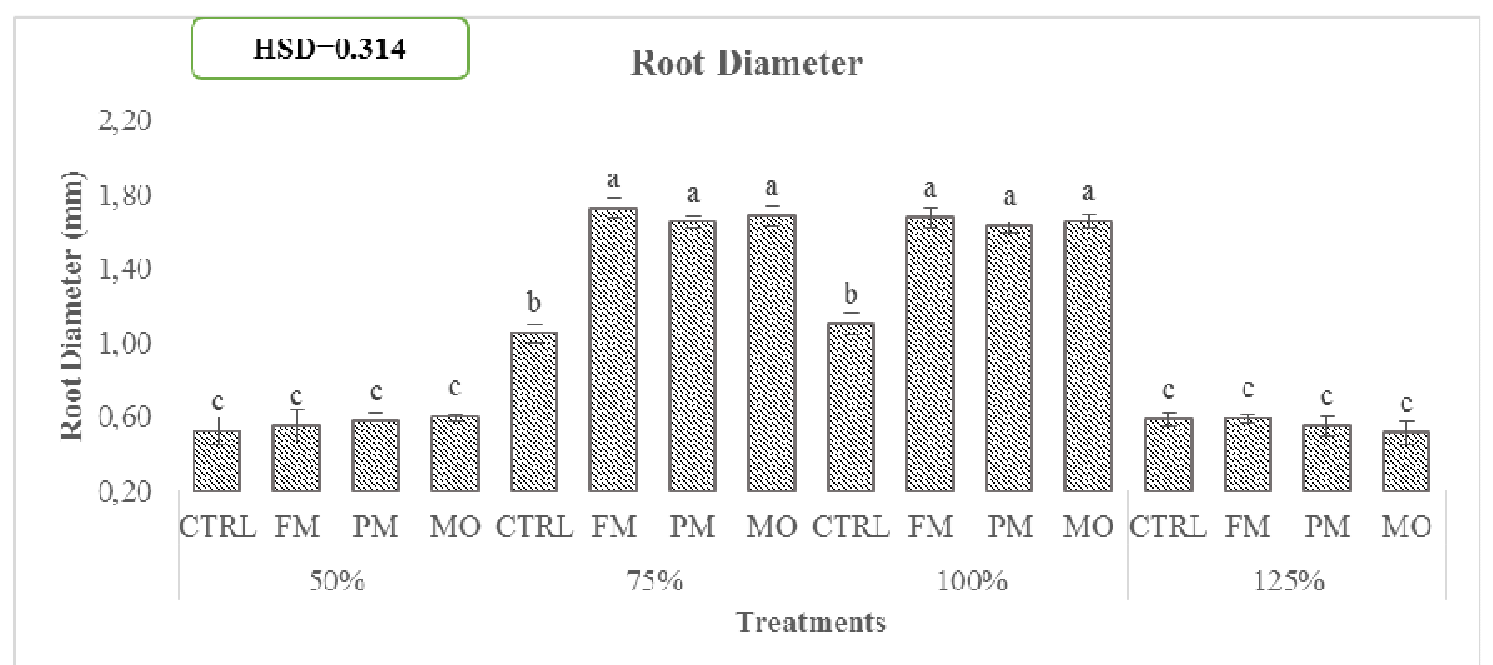

Figure 4. Effect of different organic substrates on root average diameter $(\mathrm{mm})$ at different water stress levels

\section{DISCUSSION}

Plant growth is dependent upon the soil nutritional value, more obviously, the nutrients in solution contribute towards growth. The nutrient availability and uptake are dependent upon soil physicochemical health, especially water content of soil, organic carbon and the soil biological activities. Different organic manures at maintained moistures have contributed differently to plant growth as presented in results of plant growth parameters. Shoot growth i.e. plant height, shoot fresh and shoot dry matter increased significantly due to better root growth that promoted water and nutrient uptake. Plant root is the main soldier present at that border having access to these obstacles. $\mathrm{N}$ incorporation increases protein and enzyme contents enduring plants better physiological activism. Greater $\mathrm{N}$ contents also contributes towards chlorophyll formation that consequently enhances photosynthesis (Mia et al., 2005).

Organic substrates addition resulted in improved plant vegetative (height, fresh and dry biomass of maize plants) growth (Table-2). This improvement maybe due to direct nutrient supplementation or by indirect amendment of soil physical characteristics i.e. soil structure and water retention capacity, bulk density, penetration resistance and porosity, infiltration rate (HATI et al., 2008). Improved soil health provides conducive environment for root development that stimulate plant growth. Sensible use of organic manures along with synthetic fertilizers and irrigation are essential to safeguard soil health and augment input use efficacy and productivity (HATI et al., 2006; 
BHATTACHARYYA et al., 2008). Positive response of productivity with integrated application of manure and synthetic fertilizers have been reported by many researchers (BANDYOPADHYAY et al., 2003; GHOSH et al., 2006; HATI et al., 2000; MANDAL et al., 2000; SINGH et al., 1999). Plant growth criterion imitate the net flux of resources in and out of plant and its various organs. However, each resource maybe invested differently and provide different insights into plant's adaptive mechanisms and physiological balance (HAMANN et al., 2017). Several workers (EL-DARIER et al., 2002; POSPISIL et al., 2006) analyzed biomass accumulation and growth patterns with respect to plant variety, spacing, nutrient, organics and water management regimes.

Soil moisture is one of the most important factor for poor growth and yield of crops. One possible mean to exploit growth per water drop is deficit irrigation (English and Raja, 1996). Saving of water is more beneficial than reduced yields by regulated deficit irrigation, specifically in water limited areas (KIRDA, 2002). A linear relation is present in crop growth and irrigation levels and the deficit irrigation at booting and heading delays reproduction resulting into $25 \%$ increase in yield of wheat crop (ALDERFASI; REFAY, 2010). The present experiment also indicates statistically similar growth pattern where soil moisture was kept @ 75\% of AWC (Table-2 \& 3). Moisture deficit reduces yield but increases biomass as well the water use capacity of plants (MAHAMED et al., 2011; HAMED et al., 2015). Limited water supply up to $75 \%$ of AWC massive growth of plant roots was observed yielding higher root masses and length densities (mentioned in Table 3 and Figure 2.
SHAHZAD, H. et al.

Imran et al. (2015) had reported more root length density at $70-80 \%$ of available water capacity at different crop growth stages. A provocative change in root penetration pattern, increase in root length density was observed with irrigation at different crop growth stages (XUE et al., 2003) and the reduced irrigation yielding highest length density of roots in deeper soil (QUANQI et al., 2010). Drying of soil during early crop growth stages stimulate root growth especially in deeper soil profile (ZHANG et al., 2006). Variances in soil moisture storage and uptake under different organic and inorganic applications is more evident during dry spell (BANDYOPADHYAY et al., 2003). The incorporation of organic substrates increases soil organic carbon pool increasing biological activities that results in improved soil physical health leading to more proliferation of roots making water availability much easier for plants, that ultimately results in more growth (CORBEELS et al., 1998). Roots mostly prevailed in upper $15 \mathrm{~cm}$ depth because of more nutrition and especially loose soil profile, but organic matter addition not only loosen the soil in deeper region but also enhances root penetration (BANDYOPADHYAY et al., 2010). Huang (2000) reported increase in root length densities in deeper soil with application of farm manure maybe attributed to nutrient supply and creation of better soil physical environments due to lowering of soil bulk density and penetration resistance and increased porosity. Decreased crop penetration resistance because of applied manures increase root length density up to $97 \%$ (HATI et al., 2006).

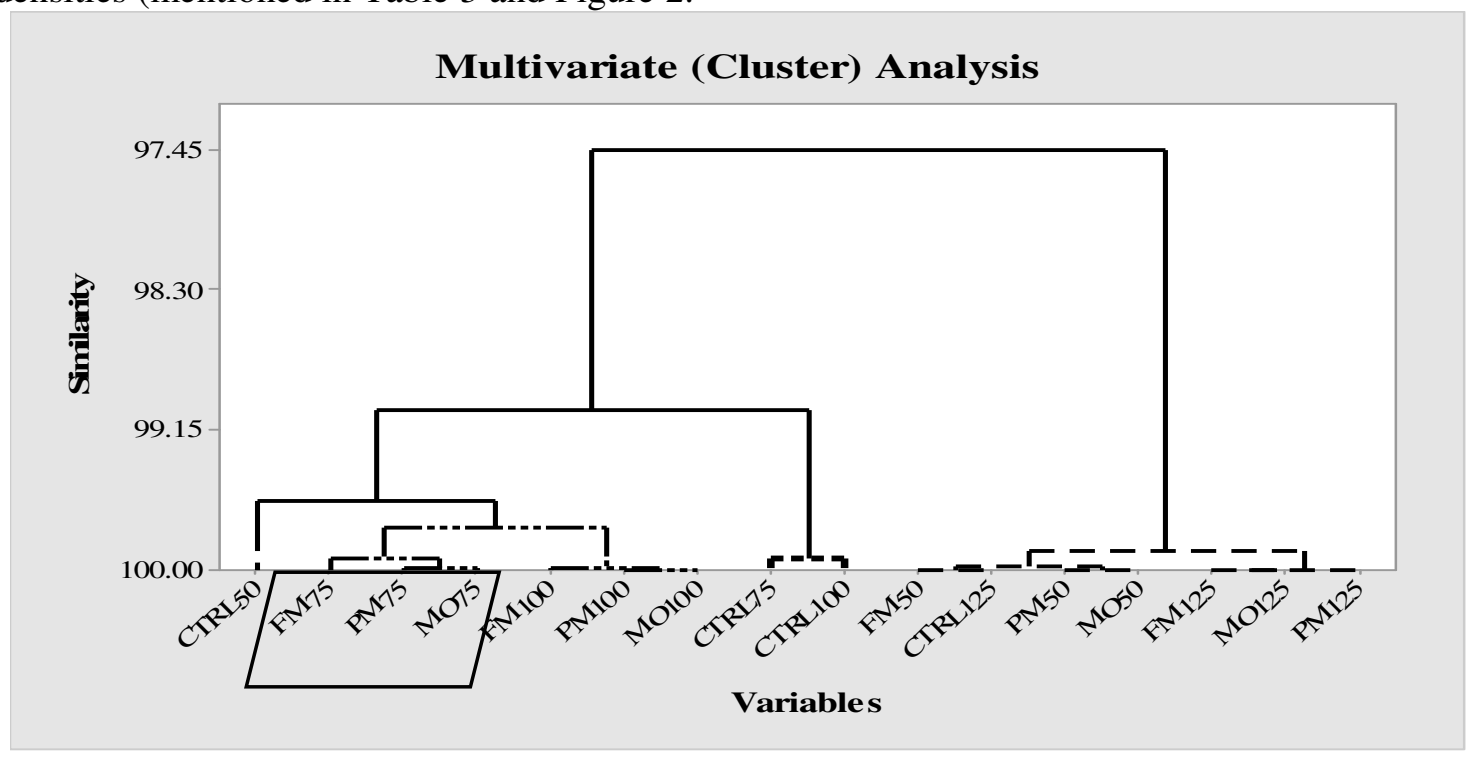




\section{CONCLUSION}

In arid and semi-arid areas of world, limited water application in combination with organic substrates has a significant impact on plant growth. This study explores the effectiveness of limited
SHAHZAD, H. et al.

water supply in combination with mixture of organic substrates on maize in semi-arid climate. The optimum level of irrigation proved to be $75 \%$ of available water contents (Multivariate Analysis) in combination with all organic substrates.

RESUMO: A ameaça agravante para a agricultura atual é a provisão de segurança alimentar para populações cada vez maiores, utilizando recursos escassos. A escassez de água está restringindo os seres humanos a produzir mais a partir de gotas de água no lugar de galões. A raiz está presente na interface solo-planta e é o principal extrator de água para a planta. Seu padrão de crescimento varia conforme as condições de umidade do solo flutuam. O presente estudo em vaso é constituído por dois fatores, ou seja, substratos orgânicos (esterco bovino, esterco de aves e melaço) e diferentes níveis de stress hídrico $\{50,75,100$ e $125 \%$ do teor de água disponível (AWCs) $\}$ utilizando milho como cultura de teste para avaliar o seu impacto em diferentes parâmetros de crescimento (especialmente crescimento de raiz). O experimento foi conduzido utilizando delineamento experimental inteiramente casualizado, em arranjo fatorial. Raiz radicular (44,5 cm), biomassa seca e fresca da raiz (71,1 ge $24,3 \mathrm{~g}$, respectivamente), diâmetro radicular (1,73 mm), volume radicular $(0,24$ $\mathrm{cm} 3)$ e densidade radicular $(7,4 \times 10-3 \mathrm{~cm} \mathrm{~cm}-3)$ foram observados em vasos tratados com esterco de fazenda a $75 \%$ AWC que foi estatisticamente indistinguível de todos os outros tratamentos no mesmo nível de água e $100 \%$ de disponibilidade de água, mas eloqüentemente maior que plantas de todos os tratamentos a 50\% e $125 \%$ de conteúdo de água disponível. O comprimento do rebento, peso seco e fresco foram maiores nas plantas com $100 \%$ de umidade disponível. Eles foram estatisticamente equivalentes a $75 \%$ de plantas tratadas com água. Comparando os tratamentos para todos os parâmetros na análise multivariada de clusters, concluiu-se que $75 \%$ do conteúdo de água disponível produz quase o mesmo que $100 \%$, juntamente com o benefício da segurança hídrica.

PALAVRAS-CHAVE: Orgânica. Milho. Raiz. Proliferação. Seca.

\section{REFERENCES}

ALAMI, Y.; ACHOUAK, W.; MAROL, C.; HEULIN, T. Rhizosphere soil aggregation and plant growth promotion of sunflower by an EPS-producing Rhizobium sp. isolated from sunflower roots. Applied and Environmental Microbiology, v. 66, n. 8, p. 3393-3398, aug. 2000. https://doi.org/10.1128/AEM.66.8.33933398.2000

ALDERFASI, A. A.; REFAY, Y. A. Integrated use of potassium fertilizer and water schedules on growth and yield of two wheat genotypes under arid environment in Saudi Arabia 1- Effect on growth characters.

American-Eurasian Journal of Agricultural and Environmental Sciences, v. 9, n. 3, p. 239-247, jun. 2010. https://www.researchgate.net/publication/277076794

BANDYOPADHYAY, K. K.; MISRA, A. K.; GHOSH, P. K.; HATI, K. M. Effect of integrated use of farmyard manure and chemical fertilizers on soil physical properties and productivity of soybean. Soil and Tillage Research, v. 110, n. 1 p. 115-125, sep. 2010. https://doi.org/10.1016/j.still.2010.07.007 BANDYOPADHYAY, K. K.; MISRA, A. K.; GHOSH, P. K.; HATI, K. M.; MANDAL, K. G. Effect of integrated use of farmyard manure and inorganic fertilizers on soil water dynamics, root growth, crop yield and water expense efficiency of rainfed soybean in a Vertisol. Journal of Agricultural Physics, v. 3, n. (1-2), p. 95-100, apr. 2003. http://www.agrophysics.in/Published/2003/2003-paper-15.pdf

BHATTACHARYYA, R.; KUNDU, S.; PRAKASH, V.; GUPTA, H. S. Sustainability under combined application of mineral and organic fertilizers in a rainfed soybean-wheat system of Indian Himalayas. European Journal of Agronomy, v. 28, n. 1, p. 33-46, jan. 2008. https://doi.org/10.1016/j.eja.2007.04.006 
CORBEELS, M.; HOFFAMAN, G.; VAN CLEEMPUT, O. Analysis of water use by wheat grown on a cracking clay soil in a semi-arid Mediterranean environment: weather and nitrogen effects. Agricultural Water Management, v. 38, n. 2, p. 147-167, dec. 1998. https://doi.org/10.1016/S0378-3774(98)00062-6

DANE, J. H.; HOPMANS, J. W. Laboratory determination of water retention. In: DANEA, J. H.; TOPP, G. C. (Ed.). Methods of Soil Analysis. Part 4, Physical Methods. Soil Science Society of America Inc., Madison, WI, USA, 2002. p. 671-720.

DANNOURA, M.; KOMINAMI, Y.; OGUMA, H.; KANAZAWA, Y. The development of an optical scanner method for observation of plant root dynamics. Plant Root, v. 2, p. 14-18, apr. 2008.

https://doi.org/10.3117/plantroot.2.14

DAWE, D.; DOBERMANN, A.; MOYA, P.; ABDULRACHMAN, S.; SINGH, B.; LAL, P.; LI, S. Y.; LIN, B.; PANAULLAH, G.; SARIAM, O.; SINGH, Y.; SWARUP, A.; TAN, P. S.; ZHEN, Q. X. How widespread are yield declines in long term rice experiments in Asia? Field Crops Research, v. 66, n. 2, p. 175-193, may. 2000. https://doi.org/10.1016/S0378-4290(00)00075-7

DUXBURY, J. M.; ABROL, I. P.; GUPTA, R. K.; BRONSON, K. F. Analysis of long-term soil fertility experiments with rice-wheat rotations in South Asia. In: Long-Term Soil Fertility Experiments with RiceWheat Rotations in South Asia. Rice-Wheat Consortium Paper Series, v. 6, p. 7-22, 2000.

DWYER, L. M.; STEWART, D. W.; BALCHIN, D. Accurately monitoring and maintaining soil water in greenhouse containers. Canadian Agricultural Engineering, v. 29, n. 1, p. 89-91, jan. 1987. http://www.csbescgab.ca/docs/journal/29/29_1_89_ocr.pdf

EL-DARIER, S.; HEMADA, M.; SADEK, L. Dry matter distribution and growth analysis in soybeans under natural agricultural conditions. Pakistan Journal of Biological Sciences, v. 5, n. 5, p. 545-549, may. 2002. http://dx.doi.org/10.3923/pjbs.2002.545.549

ENGLISH, M.; RAJA, S. N. Perspectives on deficit irrigation. Agricultural Water Management, v. 32, no. 1, p. 1-14, nov. 1996. https://doi.org/10.1016/S0378-3774(96)01255-3

FANG, Q.; MA, L.; YU, Q.; AHUJA, L. R.; MALONE, R.W.; HOOGENBOOM, G. Irrigation strategies to improve the water use efficiency of wheat-maize double cropping systems in North China Plain. Agricultural Water Management, v. 97, n. 8, p. 1165-1174, aug. 2010.

https://doi.org/10.1016/j.agwat.2009.02.012

GENTINE, P.; ENTEKHABI, D.; CHEHBOUNI, A.; BOULET, G.; DUCHEMIN, B. Analysis of evaporative fraction diurnal behaviour. Agricultural and Forest Meteorology, v. 143, n. (1-2), p. 13-29, mar. 2007. https://doi.org/10.1016/j.agrformet.2006.11.002

GHOSH, P. K.; MANNA, M. C.; BANDYOPADHYAY, K. K.; AJAY; TRIPATHI, A. K.; WANJARI, R. H.; HATI, K. M.; MISRA, A. K.; ACHARYA, C. L.; SUBBA RAO, A. Interspecific interaction and nutrient use in soybean/sorghum intercropping system. Agronomy Journal, v. 98, n. 4, p. 1097-1108, jul. 2006.

http://dx.doi.org/10.2134/agronj2005.0328

HAMANN, E.; KESSELRING, H.; STÖCKLIN, J. Plant responses to simulated warming and drought: a comparative study of functional plasticity between congeneric mid and high elevation species. Journal of Plant Ecology, v. 11, n. 3, p. 364-374, apr. 2017. https://doi.org/10.1093/jpe/rtx023

HAMED, H. C. M.; REZIG, M.; NACEUR, M. B. Water use efficiency of durum wheat (Triticum durum Desf) under deficit irrigation. Journal of Agricultural Sciences, v. 7, n. 8, p. 238-249, jul. 2015.

http://dx.doi.org/10.5539/jas.v7n8p238 
HATI, K. M.; MANDAL, K. G.; MISRA, A.K. Effect of nutrient management on water use and yield of rainfed soybean grown on a cracking clay soil. Environment and Ecology, v. 18, n. 1, p. 202-206, mar. 2000. https://www.cabdirect.org/cabdirect/abstract/20000708561

HATI, K. M.; MANDAL, K. G.; MISRA, A.K.; GHOSH, P. K.; BANDYOPADHYAY, K. K.; ACHARYA, C.L. Effect of inorganic fertilizer and farmyard manure on soil physical properties, root distribution, water use efficiency and seed yield of soybean in Vertisols of Central India. Bioresource Technology, v. 97, n. 16, p. 2182-2188, nov. 2006. https://doi.org/10.1016/j.biortech.2005.09.033

HATI, K. M.; SWARUP, A.; MISHRA, B.; MANNA, M. C.; WANJARI, R. H.; MANDAL, K. G.; MISRA, A. $\mathrm{K}$. Impact of long-term application of fertilizer, manure and lime under intensive cropping on physical properties and organic carbon content of an Alfisol. Geoderma, v. 148, n. 2, p. 173-179, dec. 2008. https://doi.org/10.1016/j.geoderma.2008.09.015

HUANG, B. Role of root morphological and physiological characteristics in drought resistance of plants. In: Plant-environment interactions. CRC Press, 2000. p. 57-82.

https://www.taylorfrancis.com/books/e/9780203910023

IMRAN, M.; HASSAN, A. U.; IQBAL, M.; ULLAH, E.; SIMUNEK, J. Assessment of actual evapotranspiration and yield of wheat under different irrigation regimes with potassium application. Soil and Environment, v. 34, n. 2, p. 156-165, nov. 2015. https://escholarship.org/uc/item/18g7x5g9

JIN, M. G.; ZHANG, R. Q.; GAO, Y. F. Temporal and spatial soil water management: A case study in the Heiloonggang region, PR China. Agricultural Water Management, v. 42, n. 2, p. 173-187, nov. 1999. https://doi.org/10.1016/S0378-3774(99)00039-6

KANG, S. Z.; ZHANG, L.; LIANG, Y. L.; HU, X. T.; CAI, H. J.; GU, B. J. Effects of limited irrigation on yield and water use efficiency of winter wheat in the Loess Plateau of China. Agricultural Water Management, v. 55, n. 3, p. 203-216, jun. 2002. https://doi.org/10.1016/S0378-3774(01)00180-9

KIMBLE, J. M.; LAL, R.; FOLLET, R. F. Agricultural practices and policy options for carbon sequestration: what we know and where we need to go. In: KIMBEL, J. M.; LAL, R.; FOLLET, R. F. (Ed.). Agricultural Practices and Policies for Carbon Sequestration in Soil. Lewis: New York, 2002. p. 512.

KIRDA, C. Deficit irrigation scheduling based on plant growth stages showing water stress tolerance. Food and Agricultural Organization of the United Nations, Deficit Irrigation Practices, Water Reports, 2002.

LADHA, J. K.; DAWE, D.; PATHAK, H.; PADRE, A. T.; YADAV, R. L.; SINGH, B.; SINGH, Y.; SINGH, Y.; SINGH, P.; KUNDU, A. L.; SAKAL, R.; RAN, N.; REGMI, A. P.; GAMI, S. K.; BHANDARI, A. L.; AMIN, R.; YADAV, C. R.; BHATTARAI, E. M.; DAS, S.; AGGARWAL, H. P.; GUPTA, R. K.; HOBBS, P. R. How extensive are yield declines in long-term rice-wheat experiments in Asia? Field Crops Research, v. 81, n. (2-3), p. 159-180, feb. 2003. https://doi.org/10.1016/S0378-4290(02)00219-8

LAL, R. Carbon sequestration in dryland ecosystems. Environmental Management, v. 33, n. 4, p. 528-544, aug. 2004. https://doi.org/10.1007/s00267-003-9110-9

MAHAMED, M. B.; SAROBOL, E. D.; HORDOFA, T.; KAEWRUENG, S.; VERAWUDH, J. Effects of soil moisture depletion at different growth stages on yield and water use efficiency of bread wheat grown in semiarid conditions in Ethiopia. Kasetsart Journal (Natural Sciences), v. 45, n. 1, p. 201-208, jan. 2011.

MANDAL, K. G.; MISRA, A. K.; HATI, K. M. Effect of combination of NPK and FYM on growth, yield and agronomic efficiency of soybean (Glycine max) in Vertisol. Environment and Ecology, v. 18, n. 1, p. 207209, mar. 2000. https://www.cabdirect.org/cabdirect/abstract/20000708562 
MIA, M. A. B.; SHAMSUDDIN, Z. H.; ZAKARIA, W.; MARZIAH, M. High-yielding and quality banana production through plant growth promoting rhizobacterial (PGPR) inoculation. Fruits, v. 60, n.3, p.179-185, may. 2005. https://doi.org/10.1051/fruits:2005024

NACEUR, M. B.; NAILY, M.; SELMI, M. Effect of water deficiency during different growth stages of wheat on soil humidity and plant physiology yield components. Medit, v. 10, n. 2, p. 60-63, 1999.

PARASURAMAN, K.; ELSHORBAGY, A.; CAREY, S. K. Modelling the dynamics of the evapotranspiration process using genetic programming. Hydrological Sciences Journal, v. 52, n. 3, p. 563-578, jun. 2007. https://doi.org/10.1623/hysj.52.3.563

POSPISIL, A.; VARGA, B.; SVECNJAK, Z.; KAROVIK, K. Influence of cropping system intensity on dry matter yield and nitrogen concentration in different parts of soybean plant. Agriculturae Conspectus Scientificus, v. 71 n. 2, p. 51-57, oct. 2006. https://hrcak.srce.hr/5179

LI, Q.; BAODI, D.; YUNZHOU, Q.; MENGYU, L.; JIWANG, Z. Root growth, available soil water and water use efficiency of winter wheat under different irrigation regimes applied at different growth stages in North China. Agricultural Water Management, v. 97, n. 10, p. 1676-1682, oct. 2010.

https://doi.org/10.1016/j.agwat.2010.05.025

RILLIG, M. C.; WRIGHT, S. F.; EVINER, V. T. The role of arbuscular mycorrhizal fungi and glomalin in soil aggregation: Comparing effects of five plant species. Plant and Soil, v. 238, n. 2, p. 325-333, jan. 2002. https://doi.org/10.1023/A:1014483303813

SCHREINER, R. P.; MIHARA, K. L.; MCDANIEL, H.; BETHLENFALVAY, G. J. Mycorrhizal fungi influence plant and soil functions and interactions. Plant and Soil, v. 188, n. 2, p. 199-209, jan. 1997. https://doi.org/10.1023/A:1004271525014

SINGH; MUNESHWAR; TRIPATHI, A. K.; KUNDU, S.; TAKKAR, P.N.; SINGH, M. Nitrogen requirement of soybean (Glycine max)-wheat (Triticumaestivum) cropping system and biological $\mathrm{N}$ fixation as influenced by integrated use of fertilizer $\mathrm{N}$ and farmyard manure in Typic Haplustert. Indian Journal of Agricultural Sciences, v. 69 n. 5, p. 379-381, may. 1999.

TANDON, H. L. S. Organic residues: an assessment of potential supplies their contribution to agricultural productivity and policy issues for Indian agriculture from 2000 to 2025. In: KANWAR, I. S.; KATYAL, S. C. (Ed.). Plant needs, Supply, Efficiency and Policy Issues: 2000-2025. National Academy of Agricultural Sciences, New Delhi, India. 1997.

VAUX, J. H. J.; PRUITT, W. O. Crop-water production functions. In: HILLEL, D. (Ed.), Advances in Irrigation 2. Academic Press, New York: 1983. p. 61-97.

WANG, H. X.; LIU, C. M.; ZHANG, L. Water-saving agriculture in China: An overview. Advances in Agronomy, v. 75, p. 135-171, 2002. https://doi.org/10.1016/S0065-2113(02)75004-9

WILLIAMS, J.; PREBBLE, R. E.; WILLIAMS, W. T.; HIGNETT, C. T. The influence of texture, structure and clay mineralogy on the soil moisture characteristic. Australian Journal of Soil Research, v. 21, n. 1, p. 15-32, jan. 1983. https://doi.org/10.1071/SR9830015

XUE, Q.; ZHU, Z.; MUSICK, J. T.; STEWART, B. A.; DUSEK, D. A. Root growth and water uptake in winter wheat under deficit irrigation. Plant and Soil, v. 257, n. 1, p. 151-161, nov. 2003.

https://doi.org/10.1023/A:1026230527597

ZHANG, B.; LI, F. M.; HUANG, G.; CHENG, Z.Y.; ZHANG, Y. Yield performance of spring wheat improved by regulated deficit irrigation in an arid area. Agricultural Water Management, v. 79, n. 1, p. 28-42, jan. 2006. https://doi.org/10.1016/j.agwat.2005.02.007 